\title{
Influence of Choice of Structural System \& In-Fill Masonry on the Embodied Energy \& Cost of a Low-Rise Residential Urban-Building Indian Case Study
}

\author{
B. N. Varsha, S. Raghunath, Mangala Keshava \\ Department of Civil Engineering, BMS College of Engineering, Bengaluru, India \\ Email:varsha.bhushana@gmail.com,raghunath.smrc@gmail.com,mk.civ@bmsce.ac.in
}

How to cite this paper: Varsha, B.N., Raghunath, S. and Keshava, M. (2017) Influence of Choice of Structural System \& In-Fill Masonry on the Embodied Energy \& Cost of a Low-Rise Residential UrbanBuilding Indian Case Study Open Journal of Energy Efficiency, 6, 41-60. https://doi.org/10.4236/ojee.2017.61003

Received: December 8, 2016

Accepted: March 28, 2017

Published: March 31, 2017

Copyright $\odot 2017$ by authors and Scientific Research Publishing Inc. This work is licensed under the Creative Commons Attribution International License (CC BY 4.0).

http://creativecommons.org/licenses/by/4.0/

\section{c) (i) Open Access}

\begin{abstract}
In the urban residential building stock, a major proportion is constituted by low-rise individual buildings. In addition to cost, quality and duration, energy consumed for the project needs to be accounted in the decision making process. Minimizing the cost of construction without compromising on the architectural and structural requirements is the primary objective of the residential buildings of stake-holders, especially the owners. The choice of structural system and the materials used for construction play a crucial role in this effort. This means that the use of expensive and/or voluminous materials such as cement, steel, masonry etc. is optimized. This could lead to significant reduction in embodied energy as well, if the choice of the structural system is prudently made. In this paper, an attempt has been made to quantify the cost and embodied energy benefits for a low-rise residential building by choosing two different structural systems, namely moment resisting framed (MRF) construction system and the partly load-bearing (PLB) system. The influence of choice of materials, contributing to reduction of cost and/or energy is discussed. It is clearly noticed that, when the structural system is re-configured as a PLB system from the existing MRF system there is significant reduction in cost and embodied energy without changing the architectural form.
\end{abstract}

\section{Keywords}

Embodied Energy, Initial Cost, Structural System, Masonry

Alternatives, Low-Rise Residential Buildings

\section{Introduction}

Building construction involves assembling a wide range of materials from different sources to provide the required structural design, serviceability and aes- 
thetics. During this process the major concern is the project cost and the quality of the materials that go into construction. Along with cost and quality, the duration of the project is also of great importance. With the increase in the affordability among the urbanites, they look for constructing their unique dream houses with their desired specifications. In doing so, the stakeholders tend to oversee if the particular choice considered is the only option available to serve the purpose and at what cost is it being used. This is important because almost all the primary building materials like cement, steel, aggregates, timber etc. are expensive due to their extensive use and shortage in their availability, also some of these materials-cement and steel are energy-intensive. There is a rise in concern to monitor the built-up environment to bring down energy, cost and to educate individuals regarding the alternatives available. Due to this, the concept of "Life cycle energy" of the building is gaining prominence. Along with cost, quality and duration, the energy consumed for the project should also be added as one of the dimensions for the decision making process.

Building consumes energy at every stage of its material production, transportation, execution, maintenance and demolition. It is necessary to take up critical decision making processes during the initial design stage of building so as to reduce the total life cycle energy of the building. Life cycle energy of the building involves the summation of embodied energy, operational energy, maintenance energy and demolition energy. The energy required to initially produce the building is referred as embodied energy. It includes the energy used for the extraction, the processing and the manufacture of the materials of the building as well as their transportation and assembly on site. Operational energy is the energy used to operate the building, in other terms, provide heating, cooling, lighting and power the various appliances of the building. Maintenance of energy is needed to refurbish and maintain the building over its lifetime. The energy is used to demolish and dispose of the building at the end of its life accounts for demolition energy. By carefully assessing the properties of materials for construction, embodied energy of the building can be controlled. Today it is possible to make the building operate at very low operational energy by the use of passive ventilations and from the advent of energy efficient appliances. Use of materials with long life span and those which can be reused and recycled contribute to the reduction in maintenance energy and leads to material conservation [1] [2].

In addition to life cycle energy of a building, there are also cost components which play a vital role in the decision making processes. This includes capital cost, operational cost, maintenance cost and demolition cost which have to be considered when carrying out the life cycle analysis of building with respect to financial considerations. This paper discusses the relation between embodied energy and initial cost of construction.

It is essential that the initial investments of energy and cost, namely embodied energy and initial cost of construction should be made wisely. Once the building is constructed, it is impossible to reduce these parameters and at further stages 
any change introduced will contribute to increase in the energy and cost. Therefore by preparing a good initial design plan, carefully selecting the materials and having fewer re-works the buildings' embodied energy and cost can be optimized [3] [4].

\section{Residential Building Typologies in Bengaluru}

Globally, owning a house is among the most cherished aspirations of an individual. Due to urbanization, cities are growing ever so rapidly leading to a high demand for land. Vertical growth seems to be a normal solution in solving the housing demands in any city. An on-site walk-down survey conducted for different wards in Bengaluru highlighted the variations observed in residential housing stock for a typical urban Indian city. The buildings can be categorized based on occupancy and height as in Table 1.

The low-rise individual tenements account to nearly $35 \%$ of the building stock as shown in Figure 1. These are the projects which are initiated and controlled by owner driven decisions, here changes made are owners' choice as compared to the other building typologies where most of the decisions are policy driven as they are usually initiated and controlled by a project development organization or by the Government, where there are a number of stakeholders.

Structurally low-rise buildings can be configured as Moment Resisting Frames (MRF) or as Load-bearing masonry. The preference for constructing a loadbearing masonry structure is declining of late. Most of the contemporary architects and structural engineers have started designing and configuring low-rise residential buildings as reinforced concrete framed structures. These MRF structures are perceived to offer greater flexibility of design, especially in floor plans. One of the other important reasons for the choice of MRF construction is that

Table 1. Typical urban residential building typologies.

\begin{tabular}{ccc}
\hline$\#$ & Typical urban residential building typology & Type of structural design \\
\hline 1 & Single storied individual tenements & Reinforced Concrete/Masonry \\
2 & $2-3$ storied individual tenements & Reinforced Concrete/Masonry \\
3 & Multi-Storied apartments (7 - 30 stories) & Reinforced Concrete \\
4 & Residential quarters-Group housing (2-5 stories) & Reinforced Concrete/Masonry \\
5 & Low income group houses & Reinforced Concrete/Masonry \\
\hline
\end{tabular}

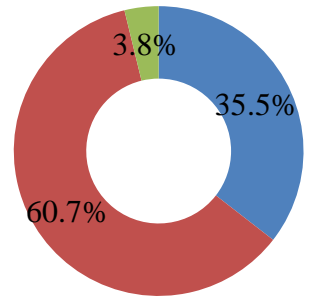

- Low-rise (1 to 3 stories)

- Mid-rise (4 to 6 stories)

- High-rise (more than 7 stories)

Figure 1. Classification of residential buildings based on on-site walk-down survey. 
the "open ground storey" can be incorporated. This is almost essential in the urban context, to allow for parking of vehicles. Also, all the interior walls can be made thinner, thereby increasing the "carpet area" On the other hand, and these issues cannot be addressed easily in load-bearing masonry system.

Structurally, load-bearing system is an ideal configuration if the floor plans are identical and the number of stories is limited to say three to four. This is because load-bearing masonry system dominantly develops compressive stress which is of less intensity due to large foot print area of the walls. All the loadbearing walls share the vertical load over their entire length where as in a MRF structure; the vertical loads are concentrated at the location of the columns alone. Also the load-bearing systems are almost devoid of huge bending moment which is very high in MRF system.

It would be an interesting exercise to combine the relative merits of both MRF system and load-bearing system. Indeed such building configurations (termed here as partly load-bearing (PLB) structures) are not uncommon in Bengaluru, especially in relatively small residential plots. The case studies taken up in the present work are one such building which is amenable to be re-configured as PLB system. Of course any change in the structural configuration has an influence on energy and cost.

\section{Objectives}

The objectives of the present work can be listed as follows

- To compute the embodied energy and initial cost of construction of a typical ground floor plus two storied individual tenement constructed as moment resisting frame (MRF);

- Re-configure MRF as partly load-bearing (PLB) system and study the variation in embodied energy and cost;

- Study the influence of alternative structural configurations and alternative masonry on embodied energy and cost of the residential building.

\section{Present Study}

Low-rise structures constitute to a bulk of residential buildings in India. Even in the modern context, a significant share of residential plot is allocated for construction of 2 - 3 storied houses. Many of such houses are constructed keeping in mind the contemporary aspirations of the mid-income-group families. Bengaluru is a typical example of one such city where one can notice a wide spectrum of architectural forms in the low-rise structures, be it in the older wards of the city or in the growing suburban. A typical street as shown in Figure 2 in both the old and new wards would consist of such 2 - 3 storied houses, each of them being distinct; yet catering to similar social character of the region.

For the analysis, majority of the embodied energy values of different building materials are considered from on-going research work and published literature pertaining to Bengaluru region [5]. Few values are considered from Inventory of Carbon and Energy (ICE), University of Bath [6] and other literatures [7] [8] [9]. 
In the present study all costs considered are cost of the material only and labor costs are not considered. Cost of the materials is assigned based on the Karnataka State Government Schedule of Rates [10]. The embodied energy and cost of basic materials used in this study are listed in Table 2. It has to be mentioned that for each of the materials there is a range of embodied energy value available in literature. Hence, to accommodate all possibilities the maximum and minimum reported values have been listed along with the considered values used for the present investigation. Similar range exists in cost of materials depending on the local conditions.
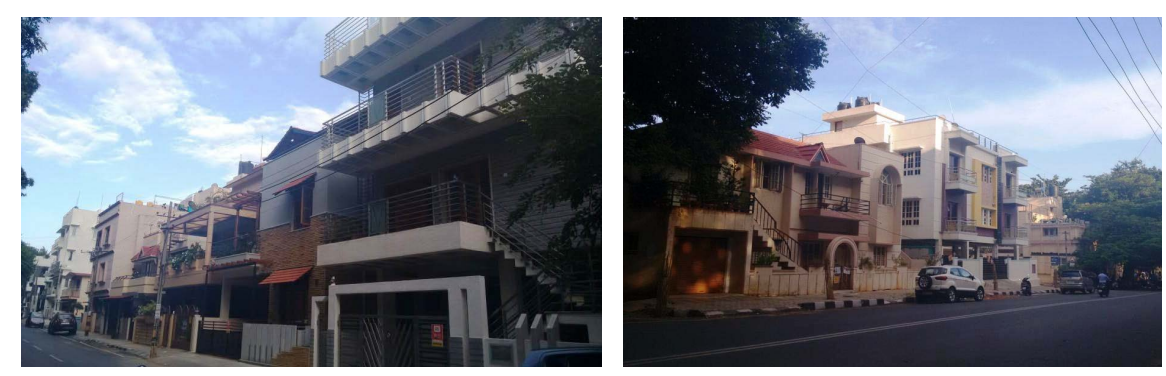

Figure 2. Street view showing typical low-rise residential buildings.

Table 2. EE and cost of basic materials.

\begin{tabular}{|c|c|c|c|c|c|c|c|c|}
\hline \multirow[b]{2}{*}{$\#$} & \multirow[b]{2}{*}{ Material } & \multirow[b]{2}{*}{ Specification } & \multicolumn{4}{|c|}{ Embodied Energy } & \multirow[b]{2}{*}{ Unit } & \multirow[b]{2}{*}{$\begin{array}{c}\text { Cost } \\
\text { (INR) }\end{array}$} \\
\hline & & & Unit & 莺 & 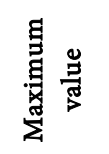 & 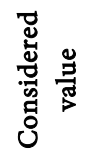 & & \\
\hline 1 & Cement & Portland Cement & $\mathrm{MJ} / \mathrm{m}^{3}$ & 5184 & 9648 & 5184 & per $\mathrm{m}^{3}$ & 16,800 \\
\hline \multirow{2}{*}{2} & \multirow{2}{*}{ Sand } & Natural & $\mathrm{MJ} / \mathrm{m}^{3}$ & 153.7 & 175 & 153.7 & per $\mathrm{m}^{3}$ & 1450 \\
\hline & & Manufactured & $\mathrm{MJ} / \mathrm{m}^{3}$ & 132.35 & 223.85 & 223.85 & per $\mathrm{m}^{3}$ & 1450 \\
\hline 3 & Gravel & $\begin{array}{l}\text { Crushed stone, } \\
\text { gravel/chipping }\end{array}$ & $\mathrm{MJ} / \mathrm{m}^{3}$ & 183.25 & 186.29 & 186.29 & per $\mathrm{m}^{3}$ & 900 \\
\hline 4 & $\begin{array}{c}\text { Reinforcement } \\
\text { Steel }\end{array}$ & \multirow[t]{2}{*}{ HYSD Bar } & $\mathrm{MJ} / \mathrm{kg}$ & 24.4 & 42 & 26.84 & per kg & 51 \\
\hline 5 & Stainless Steel & & $\mathrm{MJ} / \mathrm{kg}$ & 51.5 & 56.7 & 51.5 & per kg & 288 \\
\hline 6 & In-fill Masonry & $\begin{array}{c}\text { Solid concrete } \\
\text { block- } 400 \times 200 \times 200\end{array}$ & MJ/block & 5.66 & 15.56 & 7.8 & per block & 41 \\
\hline 7 & Putty & Lime & $\mathrm{MJ} / \mathrm{kg}$ & 5.3 & 8.1 & 8.1 & per $\mathrm{m}^{3}$ & 2743 \\
\hline \multirow{3}{*}{8} & \multirow{3}{*}{ Paint } & General & $\mathrm{MJ} / \mathrm{m}^{2}$ & 20.4 & 29.12 & 25 & & \\
\hline & & Solvent borne & & & & & per liter & 198 \\
\hline & & Antifungal paint & & & & & per liter & 294 \\
\hline \multirow{4}{*}{9} & \multirow{4}{*}{$\begin{array}{l}\text { Wood/ } \\
\text { Processed } \\
\text { Wood }\end{array}$} & Frames & $\mathrm{MJ} / \mathrm{m}^{3}$ & 870.75 & 870.75 & 870.75 & & \\
\hline & & Doors & $\mathrm{MJ} / \mathrm{m}^{3}$ & 5950 & 5950 & 5950 & & \\
\hline & & Sal Wood & & & & & per $\mathrm{m}^{3}$ & 45,000 \\
\hline & & Teak Wood & & & & & per $\mathrm{m}^{3}$ & 123,000 \\
\hline \multirow{2}{*}{10} & Flooring & Polished Granite & $\mathrm{MJ} / \mathrm{m}^{3}$ & 436.5 & 436.5 & 436.5 & per $\mathrm{m}^{2}$ & 1800 \\
\hline & Material & Ceramic Tiles & $\mathrm{MJ} / \mathrm{m}^{3}$ & 15,750 & $18,602.5$ & 15,750 & per $\mathrm{m}^{2}$ & 450 \\
\hline
\end{tabular}

Note: 1 USD \$ is approx 68 INR (Rs.) and 1EUR\$ is approx 71 INR (Rs.) as on 20/12/2016. 
The study is taken up to get insights into the energy and cost patterns of a typical building typology which constitutes to nearly $35 \%$ of residential housing segment in Bengaluru, India [11]. It also helps to assess the variation in embodied energy and cost of the building due to changes in structural system and/or by replacement of masonry units through critical decision making process during initial design and planning stage of the project.

\section{Specific Case Study}

A real time case study was considered. It consists of two residences. The ground floor consists of a two bedrooms, living hall and kitchen. The first and second floor adds up to a duplex with four bedrooms, living hall and kitchen. The total built-up area is $280 \mathrm{~m}^{2}$. The study is being carried out to assess if there could have been any reduction in the energy and cost consumption, had alternate structural systems and/or materials been used in this building construction.

\subsection{As-Built Configuration-Moment Resisting Frame (MRF)}

The building is constructed as a reinforced concrete moment resisting framed structure with 1:1.5:3 proportioned concrete and high yield strength deformed bars (HYSD). Solid concrete block masonry is used as in-fills. The flooring provided is polished granite in the majority of the area, except in bath where ceramic tiles have been laid. The walls are plastered and painted throughout the building. Teak wood and Sal wood have been used for the frames and shutters of doors and windows. The typical floor plan with column and beam details is as indicated in the Figure 3. The specifications of the materials, their quantities and their respective embodied energy and cost have been listed in Table 3.

For sample embodied energy and cost calculations refer Annexure A.

From the bill of quantities prepared it was clear that the three parameters considered (volume, energy and cost) are concentrated in super-structure elements of the building. The percentage contributions from sub-structure, super-structure and finishes are indicated in Figures 4(a)-(c) respectively. To achieve a reduction in the respective quantities the first step would be to assess and reduce the super-structure elements which are predominantly made of reinforced concrete.

The quantity of different materials used in the building and their individual embodied energy and cost were computed. The Figure 5 indicates all the three parameters of major materials where the volume of the material consumed is indicated by the area of the bubble. Though obvious it is important to note that the quantity of steel consumed is very small when compared to bulk materials like sand and gravel. But the embodied energy and cost for steel is significantly higher than any other material. On the other hand in the case of polished granite and processed wood it can be noted that though embodied energy and quantity of consumption of these materials is low, the cost is on the higher side. Reinforcement steel and cement are materials which have high embodied energy and high cost, therefore if quantity of consumption of these materials is reduced then 


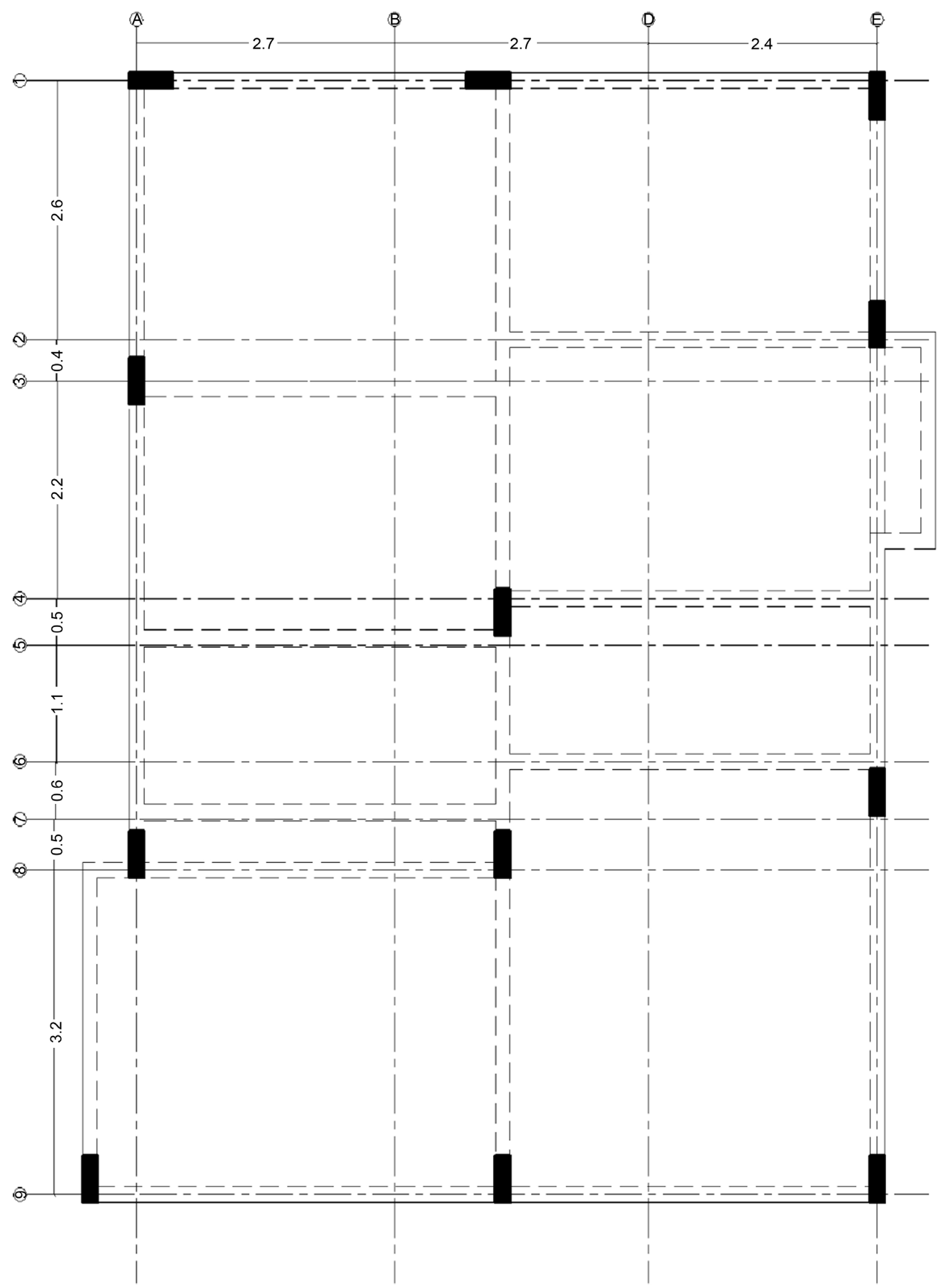

Figure 3. MRF layout. 
Table 3. Details of MRF.

\begin{tabular}{|c|c|c|c|c|c|c|}
\hline$\#$ & Type & Item & Description & $\begin{array}{l}\text { Quantity } \\
\left(\mathrm{m}^{3}\right)\end{array}$ & $\begin{array}{l}\text { Embodied } \\
\text { energy (MJ) }\end{array}$ & $\begin{array}{l}\text { Cost } \\
\text { (INR) }\end{array}$ \\
\hline 1 & \multirow{5}{*}{ 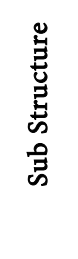 } & PCC & 1:4:8 proportion & 15 & 8981 & 35,355 \\
\hline 2 & & $\mathrm{RC}$ footing & 1:1.5:3 proportion & 11 & 35,593 & 88,471 \\
\hline 3 & & RC Pedestal & 1:1.5:3 proportion & 4 & 20,206 & 46,568 \\
\hline 4 & & Plinth Beam & 1:1.5:3 proportion & 5 & 18,245 & 44,045 \\
\hline 5 & & RC Beam & 1:1.5:3 proportion & 10 & 70,863 & 152,988 \\
\hline 6 & \multirow{4}{*}{ 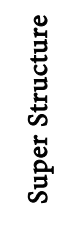 } & RC Column & 1:1.5:3 proportion & 10 & 86,036 & 175,260 \\
\hline 7 & & RC Roof slab & 1:1.5:3 proportion & 36 & 87,596 & 231,879 \\
\hline 8 & & $\begin{array}{l}\text { RC Staircase \& } \\
\quad \text { Railings }\end{array}$ & 1:1.5:3 proportion, Stainless steel & 3 & 39,228 & 170,641 \\
\hline 9 & & Lintel, Sill \& Chejja & 1:1.5:3 proportion & 10 & 24,283 & 62,589 \\
\hline 10 & \multirow{7}{*}{ 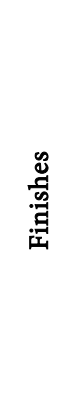 } & Block Masonry & $150 \mathrm{~mm}$ and $10 \mathrm{~mm}$ wall & 69 & 55,339 & 248,582 \\
\hline 11 & & Plastering & 1:6 mortar & 17 & 16,222 & 63,378 \\
\hline 12 & & Putty & Lime & 3 & 3772 & 8302 \\
\hline 13 & & Painting & Solvent borne & 3 & 37,834 & 67,393 \\
\hline 14 & & Door, Windows & $\begin{array}{c}\text { Sal wood \& Teak wood frames and } \\
\text { doors with steel grills }\end{array}$ & 6 & 37,956 & 364,623 \\
\hline 15 & & Flooring and Dado & Polished Granite \& Ceramic tiles & 3 & 25,242 & 353,640 \\
\hline \multicolumn{4}{|r|}{ TOTAL } & & 567,396 & $2,113,714$ \\
\hline
\end{tabular}

(a) Percentage Volume

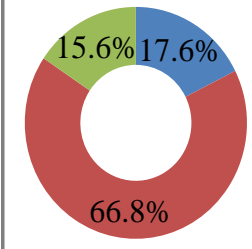

- Sub Structure

- Super Structure

Finishes
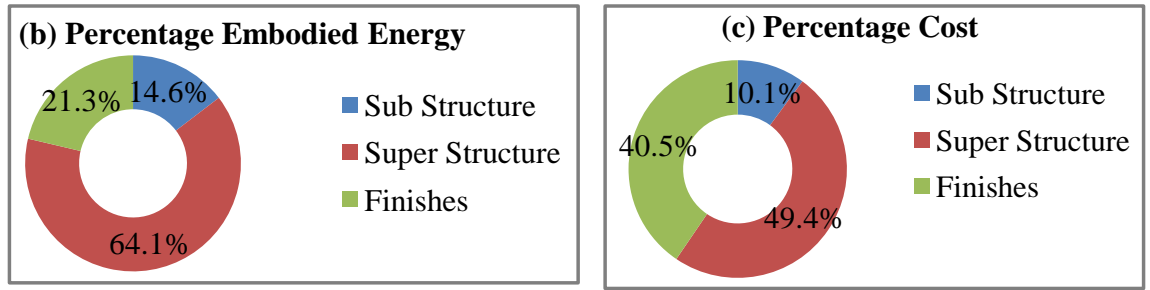

Figure 4. Percentage classification of volume, energy and cost-MRF.

Considerable savings in embodied energy and cost can be achieved.

\subsection{Alternate Structural Configuration-Partly Load-Bearing (PLB)}

To address the issue of reduction in embodied energy and cost, the building was configured as a partly load-bearing masonry system without compromising any of the functionality or serviceability of the building as offered in the previous MRF system. The configuration is based on designing the wall-above-wall as load-bearing, thereby reducing the number of columns and beams to the 


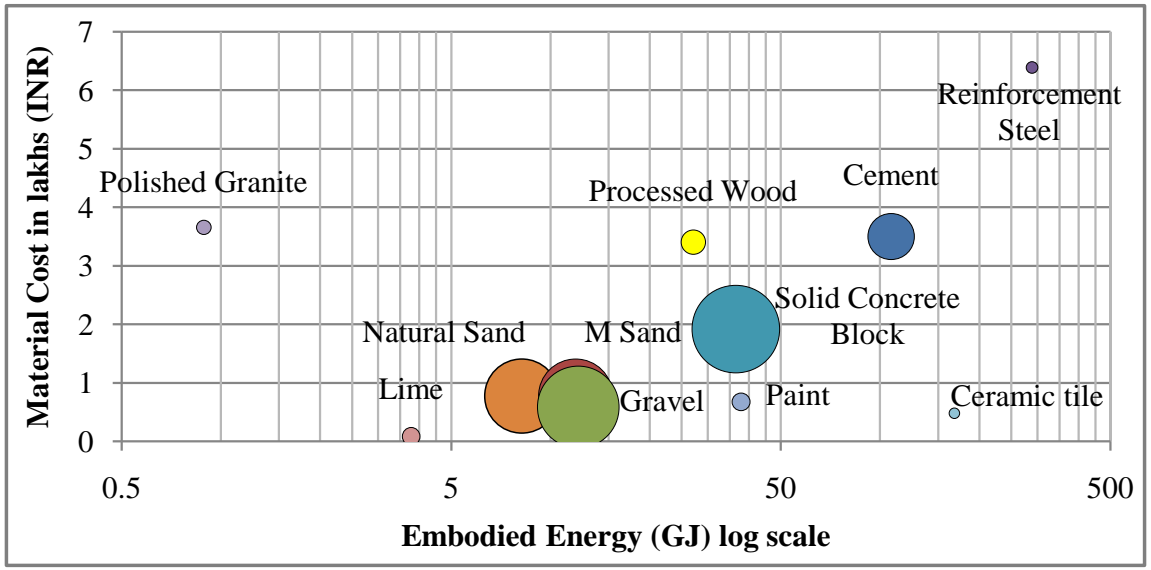

Figure 5. Bubble graph showing the material consumption-MRF.

maximum extent possible.

\section{A Brief Note on Structural Configuration of PLB Structural System}

The walls of a load-bearing masonry building are essentially configured to ensure that the structure is "stable" for all combination of loads. Thus the design approach of masonry structure is based on stability criteria. Masonry structures gain stability from the support offered by cross walls, floor/roof diaphragm and other elements such as piers. There are extensive guidelines available to ensure the stable configuration [12]. Having ensured a stable configuration, the walls are checked for load carrying capacity. If the stress developed in the walls are within the permissible stress then the design is deemed to be adequate. Thus, in a way, the design of load-bearing wall is a two-step approach. On one hand the load "transferred" (or acting) on the wall is computed, on the other hand the permissible stresses are calculated. Whilst the former is calculated based on tributary area and the latter is a function of the strength, stiffness and geometric properties of masonry and its constituent materials.

It is rather important to understand the computation of sharing of loads by masonry walls. This can be explained by a simple example of a rectangular building with four walls orthogonal to each other forming a box-type configuration. While computing the load on a pair of parallel walls it is assumed that the other two walls are redundant. Thus the entire load is deemed to be shared by the two walls. Therefore, ideally load-bearing masonry buildings should have a good disposition of walls along both the horizontal directions. This, not only helps in ensuring stability, but also in transferring the lateral loads (mainly wind and seismic loads) in proportion to their in-plane stiffness.

The load-bearing walls of the partly load-bearing system can also be designed by the above stated principles. Of course the location of the columns and beams dictate the tributary area and the loads shared thereof. It is important to note that the moments are not transferred to the un-reinforced walls at the wall-beam junction. The walls of the case study taken up are thus designed.

The load-bearing design for a typical floor is as shown in Figure 6. Size stone 


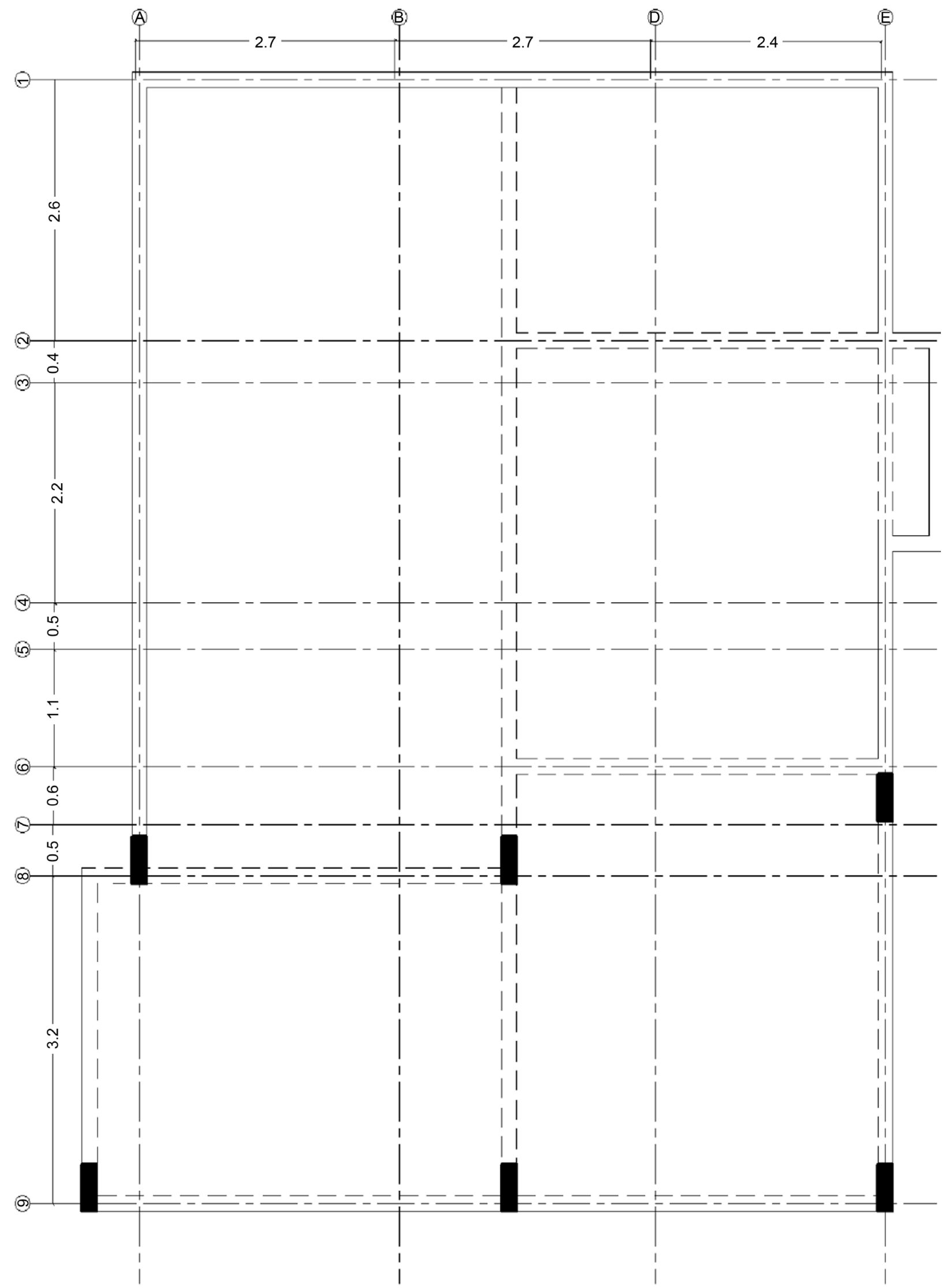

Figure 6. PLB layout. 
masonry foundation is considered and the external walls in the rear portion of the building are designed as load-bearing. Few columns could not be dispensed with, for this building, since there was a need to have a wall-free space in the car-parking space and portico in the front portion of the building. Major beams are also retained for long span slabs. Due to these changes there is a change in the slab detailing. All the finishing elements are retained as per the initial design with solid concrete blocks as the masonry element. The Table 4 shows the specifications of the materials, their quantities and their respective embodied energy and cost in the PLB design.

Figure 7 indicates the changes in embodied energy and cost of major super-structure elements due to the shift of the structural system from MRF to PLB design. The quantity of reinforced concrete elements have reduced in the

Table 4. Details of PLB.

\begin{tabular}{|c|c|c|c|c|c|c|}
\hline$\#$ & Type & Item & Description & $\begin{array}{c}\text { Quantity } \\
\left(\mathrm{m}^{3}\right)\end{array}$ & $\begin{array}{c}\text { Embodied } \\
\text { energy (MJ) }\end{array}$ & Cost (INR) \\
\hline 1 & \multirow{4}{*}{ 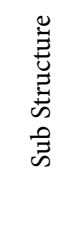 } & PCC & 1:4:8 proportion & 3 & 1922 & 7857 \\
\hline 2 & & SSM footing & 7 courses & 27 & 16,554 & 33,044 \\
\hline 3 & & Plinth Beam & 1:1.5:3 proportion & 3 & 7516 & 19,215 \\
\hline 4 & & RC Beam & 1:1.5:3 proportion & 8 & 45,280 & 100,956 \\
\hline 5 & \multirow{4}{*}{ 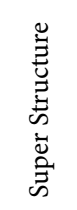 } & RC Column & 1:1.5:3 proportion & 4 & 19,518 & 42,472 \\
\hline 6 & & RC Roof slab & 1:1.5:3 proportion & 29 & 65,019 & 177,314 \\
\hline 7 & & RC Staircase \& Railings & $1: 1.5: 3$ proportion, Stainless steel & 3 & 39,163 & 170,643 \\
\hline 8 & & Lintel, Sill \& Chejja & 1:1.5:3 proportion & 10 & 24,204 & 62,589 \\
\hline 9 & \multirow{7}{*}{ 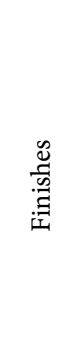 } & Block Masonry & $200 \mathrm{~mm} \& 100 \mathrm{~mm}$ wall & 89 & 59,811 & 272,296 \\
\hline 10 & & Plastering & $1: 6$ mortar & 17 & 15,176 & 63,378 \\
\hline 11 & & Putty & Lime & 3 & 3772 & 8302 \\
\hline 12 & & Painting & Solvent borne & 3 & 37,834 & 67,393 \\
\hline 13 & & Door, Windows with grill & Sal wood \& Teak wood & 6 & 37,956 & 364,623 \\
\hline 14 & & Flooring and Dado & Polished Granite \& Ceramic tiles & 3 & 22,836 & 434,497 \\
\hline \multicolumn{4}{|r|}{ TOTAL } & & 396,562 & $1,824,579$ \\
\hline
\end{tabular}

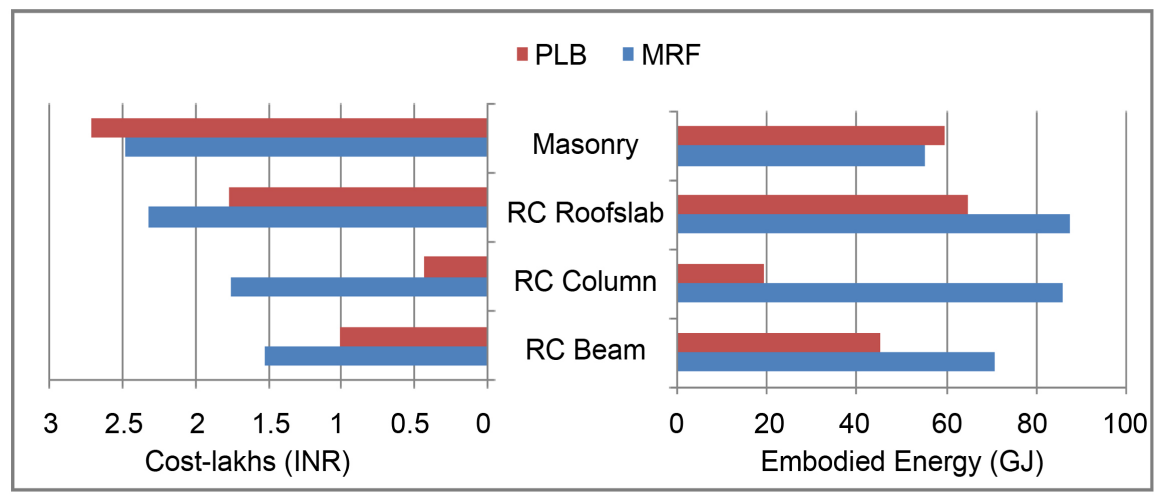

Figure 7. Variations in EE, cost and volume observed in different building components. 
PLB system as compared to the MRF there by offering a significant reduction in the embodied energy and cost. But the volume of masonry used has increased by the introduction of load-bearing walls. The higher proportion of energy and cost due to increased quantity of masonry can be brought down by choosing a more energy efficient and cost effective masonry unit as compared to solid concrete blocks.

The overall values of embodied energy, cost and quantity of steel consumed in the two designs under consideration have been graphically represented in Figure 8 , where the size of the bubble is proportional to the quantity of steel consumed. It can be observed that there is an overall reduction in embodied energy by $30 \%$. This reduction is possible mainly due to the reduction in the amount of steel consumed. The cost is reduced by $13.6 \%$ when the construction is based on PLB system. Thus, a change from MRF system to PLB system can bring about a reduction in the energy and cost in a typical residential two storied building.

\subsection{MRF with Alternate In-Fills}

Considering that the major stake-holders (owner, architect and engineer) wish to retain the structural system of the building as MRF but still need a reduction in the embodied energy and cost, then it is the choice of masonry units which needs to be reviewed. The masonry elements' contribution to percentages of volume, energy and cost parameters of the MRF building design is about $33 \%, 10 \%$ and $12 \%$ respectively when solid concrete blocks (SCB) are used.

A range of acceptable masonry units as listed in Table 5 are considered [13] and their contribution to embodied energy and cost of the project is studied. Keeping all the other building elements same as per the initial design, different masonry units are introduced for the wall element. Each masonry unit has its characteristic features namely., raw materials used, production process involved, sizes of the block available, quantity of mortar required and other factors such as wastages etc due to which there is a variation in the embodied energy and cost as indicated in Figure 9 when considered values were input. To check the range of

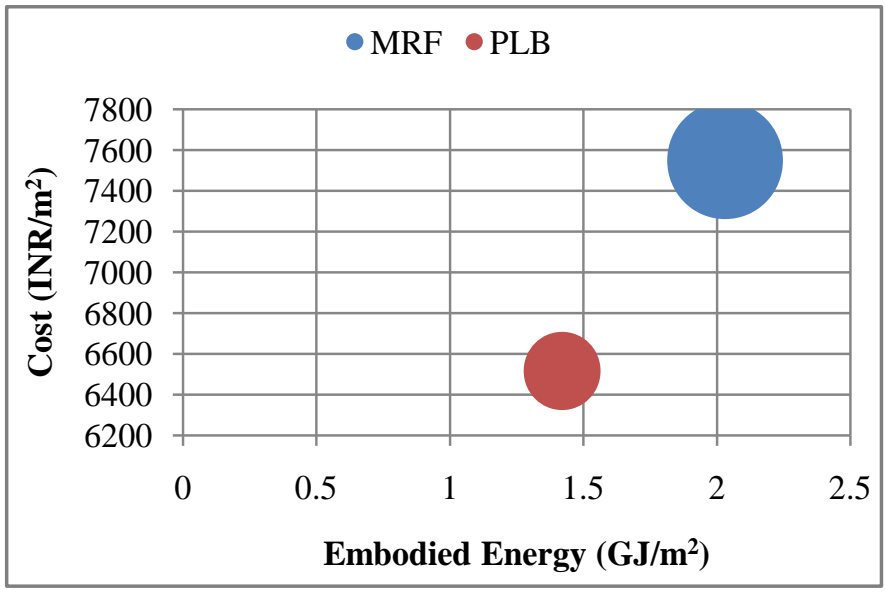

Figure 8. EE and Cost variations observed due to shift from MRF to PLB. 
Table 5. Details of acceptable in-fills.

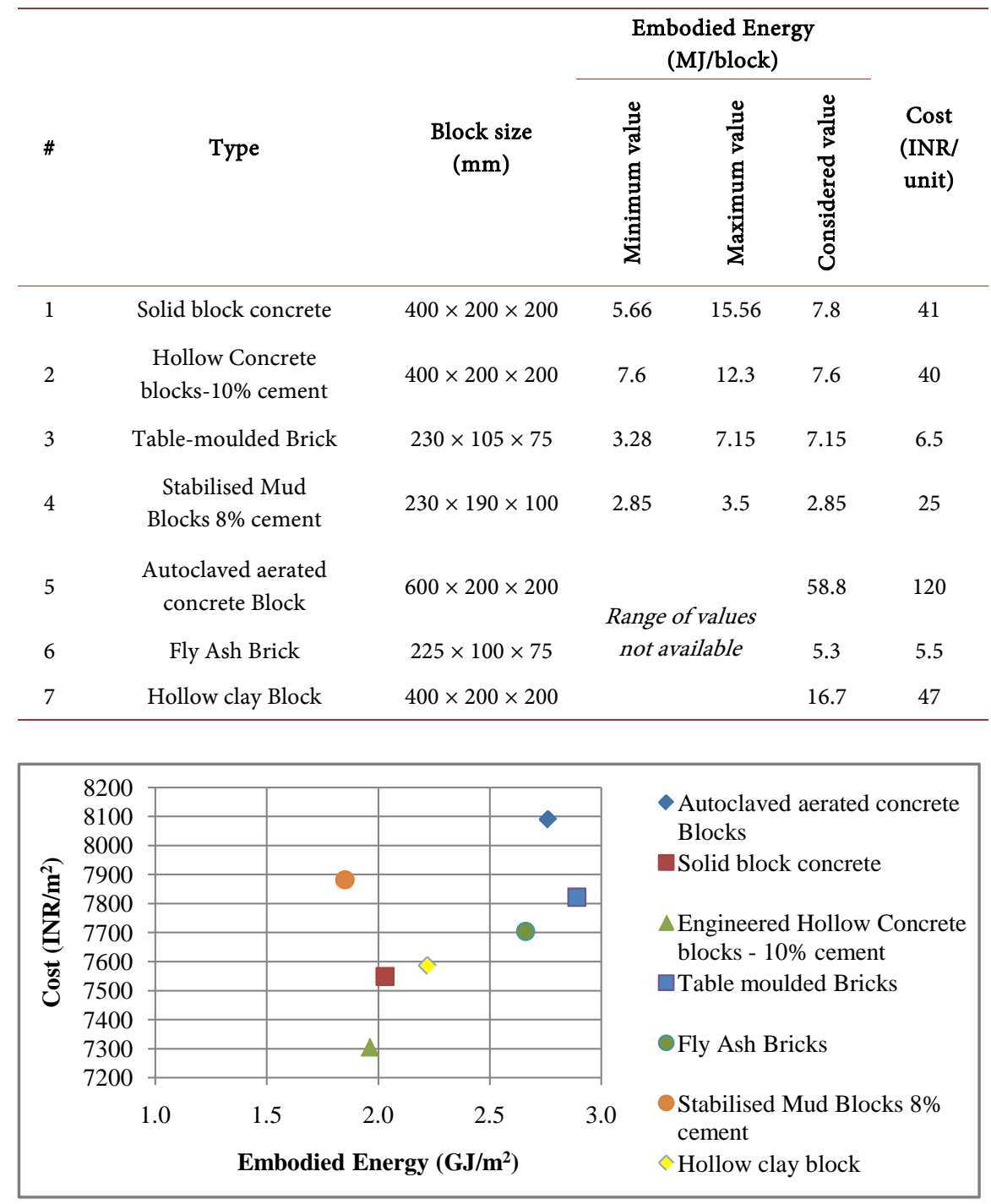

Figure 9. Variations in EE and Cost for MRF with alternate in-fills.

embodied energy value variations for the in-fills, all the minimum and maximum values were considered and the analysis was carried out. The variation is graphically represented as in Figure 10. The bottom and the top nodes indicate the minimum and maximum values of embodied energy of building when different masonry options are considered. The orange pointer indicates the value obtained through considered values.

The embodied energy of buildings constructed with stabilized mud blocks (SMB) is lower than the other alternatives. This is due to the non-requirement of any burning energy during their production and also due to the fact that very little cement is required in the preparation. Also, SMB walls do not need plastering and painting due to their aesthetic appearance, thereby saving a lot of cost and energy. The contribution of embodied energy from plastering and painting is around $3 \%$ and $7 \%$ of the total embodied energy, respectively. Thus a considerable saving can be achieved by avoiding these finishing items. Also, by replacement 
$\bullet$ Considered Value

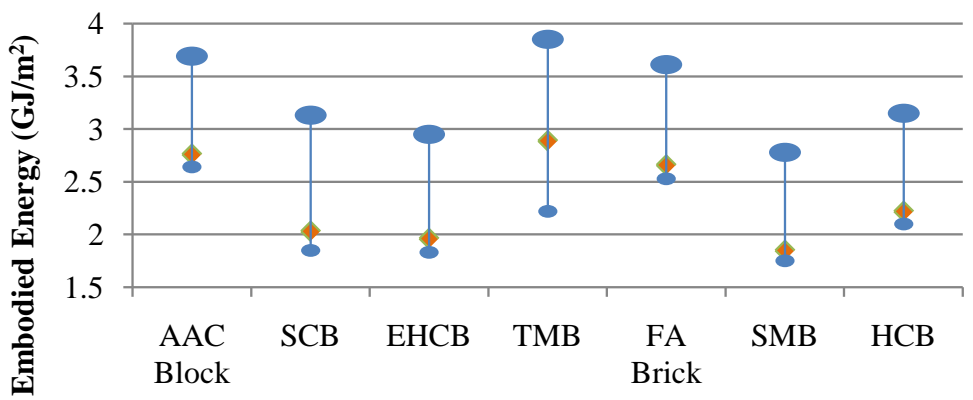

Type of in-fill masonry used

Figure 10. Variations in EE for MRF with alternate in-fills.

of existing SCB by low embodied energy SMB, up to 9\% saving in energy can be achieved.

Engineered Hollow concrete blocks (EHCB) are also energy efficient as there is reduction in volume of material consumed for the same strength characteristics when compared to a SCB. Though SMB units are less expensive when compared to $\mathrm{EHCB}$, their overall cost increases due to high mortar requirement. With EHCB as replacement, percentage saving in embodied energy and cost will be of the order $3.5 \%$ and $3.2 \%$ respectively.

Table-molded bricks (TMB) are known to be one of the most energy intensive masonry units, due to inefficient burning process at a high temperature of 8000 Cduring their production. If SCB are replaced by TMB, embodied energy of the building increases by $42 \%$. With respect to cost, the autoclaved aerated concrete (AAC) blocks are the most expensive as they involve highly automated production process. They are often transported over long distances, for instance there is no AAC block manufacturing plant near Bengaluru, they are transported from Hyderabad or Chennai. This adds to the transportation cost and hence the use of AAC blocks lead to 7\% increase in cost. Thus it can be concluded that the choice of masonry element to be considered for the building will play a crucial role.

Considering the above alternatives it is apparent that MRF buildings in combination with EHCB in-fills, lead to reduction in embodied energy and construction cost significantly.

\subsection{PLB with Alternate In-Fills}

It is already noticed that by a shift from MRF to PLB design there is a substantial saving in energy and cost. It would be a useful exercise to bring down the cost and energy further, by considering the alternative load-bearing masonry elements listed in Table 5. The pattern of energy and cost consumption of different masonry units is as indicated in Figure 11 and Figure 12. Similar trend as in previous configuration of MRF with alternate in-fills is observed; with SMB and EHCB being the most energy efficient and cost effective masonry units respectively. 


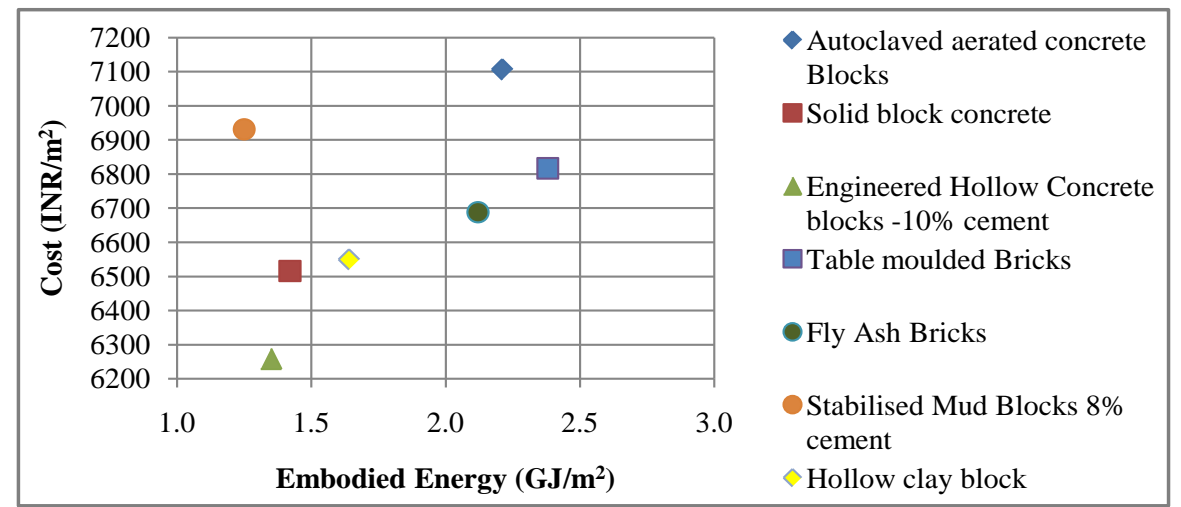

Figure 11. Variations in EE and Cost for PLB with alternate in-fills.

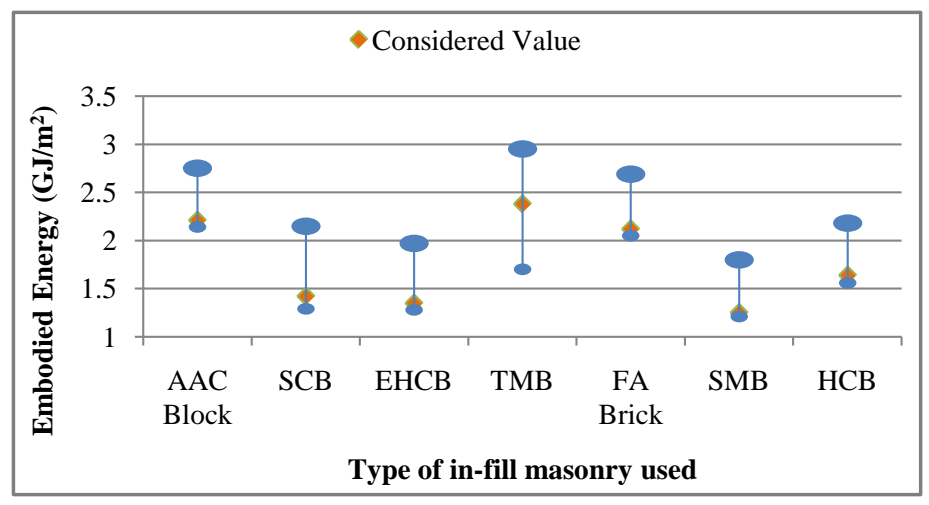

Figure 12. Variations in EE for PLB with alternate in-fills.

In PLB system, replacing SMB by SCB leads to $12 \%$ saving in energy, while, with $\mathrm{EHCB}$ as replacement, results in 5\% and 4\% savings in embodied energy and cost respectively. Thus the saving in energy and cost achieved through shift from MRF to PLB system can be further enhanced by using EHCB.

\section{Comparisons of MRF and PLB with Alternate In-Fill}

Table 6 and Table 7 show a comparison of energy and cost contributed by different combinations of in-fills and structural systems.

For the range of masonry units acceptable in an urban scenario the embodied energy of the case study varies from $1.25 \mathrm{GJ} / \mathrm{m}^{2}$ to $2.89 \mathrm{GJ} / \mathrm{m}^{2}$ depending on the choice of structural system. The cost ranges from a minimum of Rs. $6258 / \mathrm{m}^{2}$ to Rs. $8090 / \mathrm{m}^{2}$. Figure 13 is a graphical representation of these ranges of values.

It can be noted that there exists a range of values for both the structural systems. The overlapping of embodied energies values in the two structural systems is evident; however the cost of all PLB system falls lower than those of MRF system with alternate in-fills. This indicates that there is definite saving in cost that can be achieved from switching over to PLB system with any choice of alternate in-fills.

\section{Summary of Results}

In the present study a two storied residential building which is one among the 
Table 6. Variation in EE observed for masonry units with different structural system.

\begin{tabular}{cccc}
\hline \multirow{2}{*}{$\#$} & Masonry Type & \multicolumn{2}{c}{ Embodied Energy $\left(\mathrm{GJ} / \mathrm{m}^{2}\right)$} \\
\cline { 3 - 4 } & & MRF & PLB \\
\hline 1 & Autoclaved aerated concrete Blocks & 2.76 & 2.21 \\
2 & Solid block concrete & 2.03 & 1.42 \\
3 & Engineered Hollow Concrete blocks-10\% cement & 1.96 & 1.35 \\
4 & Table-moulded Bricks & 2.89 & 2.38 \\
5 & Fly Ash Bricks & 2.66 & 2.12 \\
6 & Stabilised Mud Blocks 8\% cement & 1.85 & 1.25 \\
7 & Hollow clay block & 2.22 & 1.64 \\
\hline
\end{tabular}

Table 7. Variation in Cost observed for masonry units with different structural system.

\begin{tabular}{|c|c|c|c|}
\hline \multirow{2}{*}{$\#$} & \multirow{2}{*}{ Masonry Type } & \multicolumn{2}{|c|}{ Cost $\left(\mathrm{INR} / \mathrm{m}^{2}\right)$} \\
\hline & & MRF & PLB \\
\hline 1 & Autoclaved aerated concrete Blocks & 8090 & 7106 \\
\hline 2 & Solid block concrete & 7549 & 6516 \\
\hline 3 & Engineered Hollow Concrete blocks-10\% cement & 7306 & 6258 \\
\hline 4 & Table-moulded Bricks & 7822 & 6817 \\
\hline 5 & Fly Ash Bricks & 7704 & 6688 \\
\hline 6 & Stabilised Mud Blocks $8 \%$ cement & 7882 & 6931 \\
\hline 7 & Hollow clay block & 7586 & 6550 \\
\hline
\end{tabular}

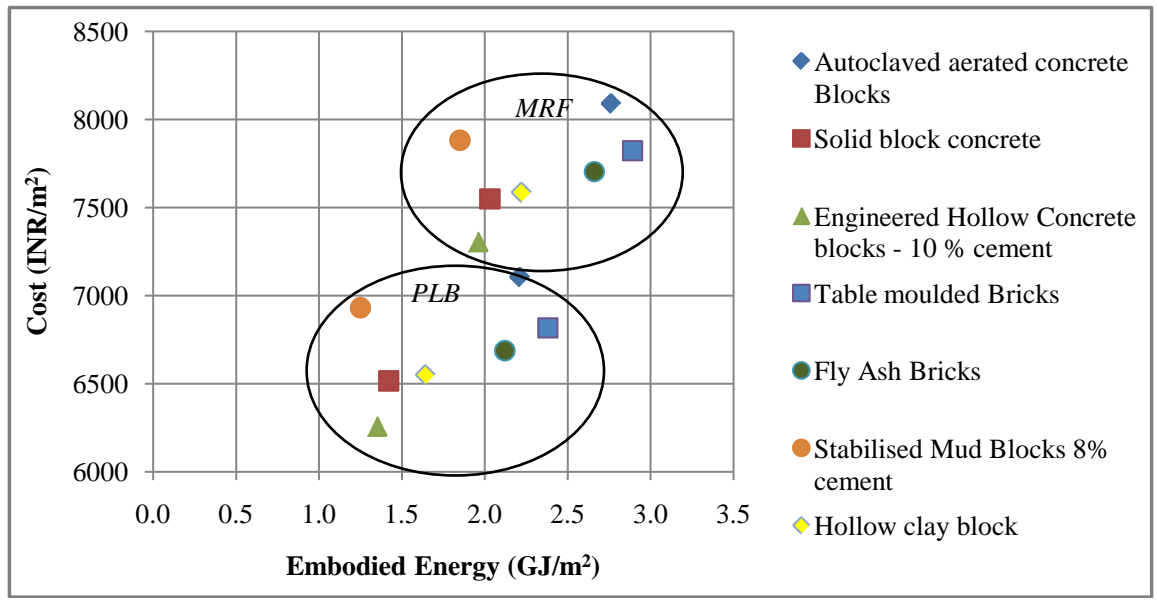

Figure 13. EE and Cost range of MRF and PLB system.

typical representatives of urban residential typology has been considered. The following set of broad conclusions can be drawn:

- Buildings re-configured as PLB system from the existing MRF system lead to reduction in embodied energy and cost [14]. From the case study it is noted that a reduction of $30 \%$ in embodied energy and $13.5 \%$ in cost is achieved.

- Major share of reduction in EE and cost is from the reduction in steel and concrete consumption both of which are energy and cost intensive materials. 
- Amongst the various alternatives for masonry it is noted that SMB (with $8 \%$ cement) followed by EHCB (with 10\% cement) are the two best alternatives with respect to EE.

- From the point of view of cost it can be concluded that EHCB (with $10 \%$ cement) is the most economical masonry option.

- Masonry alternatives with AAC blocks and WCB are not only expensive but also lead to high embodied energy.

\section{Concluding Comments}

In the present study, the two major alternatives suggested, namely PLB system in place of MRF and a variety of choices for masonry have indeed been adopted, indicating its acceptance. One can come across quite a good number of individual homes in Bengaluru with PLB systems. However, it is hard to readily recognize this system once the building gets the finishing elements. Figure 14 shows a PLB system building under construction with few columns in the front portion of the building while the rest of the building is load-bearing masonry construction. Similarly there has been a growing tendency of accepting alternative masonry especially engineered masonry units, namely EHCB and SMB. Figure 15 and Figure 16 show examples of such buildings which are being accepted

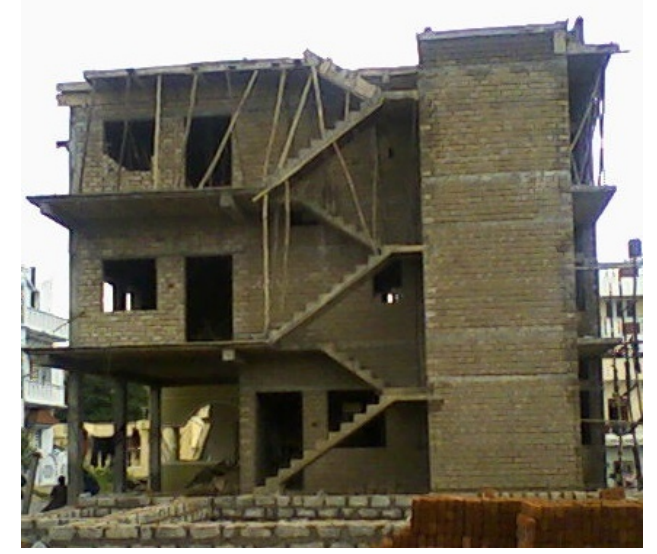

Figure 14. Residence under construction with PLB system.

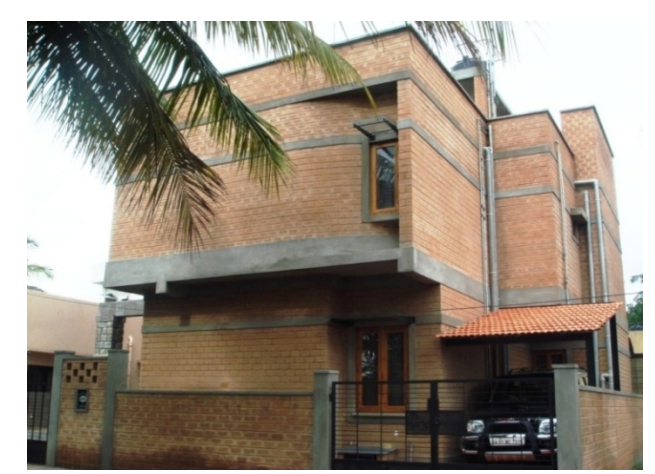

Figure 15. Residence constructed with Stabilised Mud Block. 


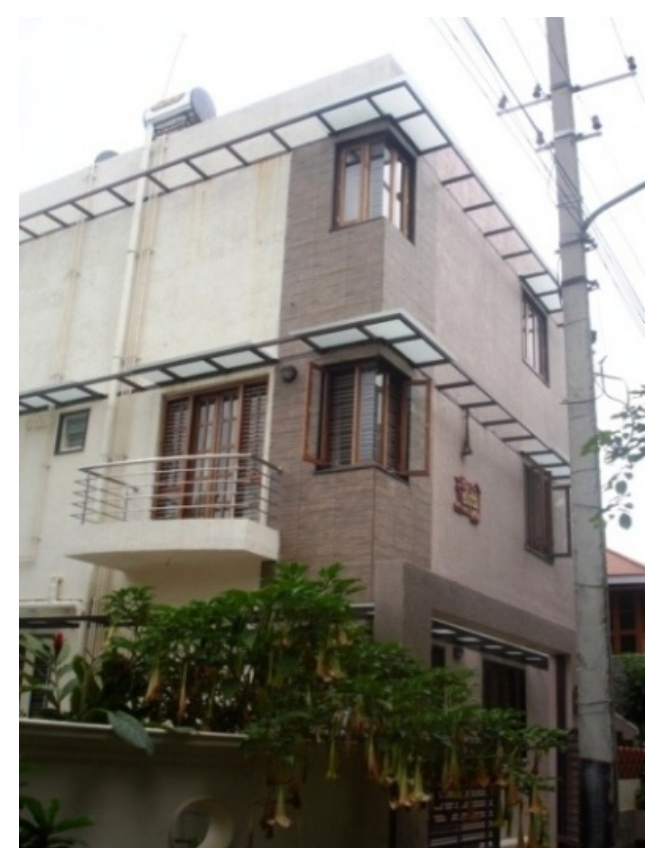

Figure 16. Residence constructed with Hollow concrete block.

amongst the peer group of the society. There is a need to promote such cost and energy effective alternatives. Any discussion related to suggesting alternatives to residential buildings, especially to the stakeholders of individual houses would be found lacking if the issue related to social acceptance is not brought in.

\section{Acknowledgements}

The work reported in this paper is supported by BMS College of Engineering, Bengaluru, through Technical Education Quality Improvement Programme [TEQIP-II] of the Ministry of Human Resource Development, Government of India.

\section{References}

[1] Ramesh, T., Ravi, P. and Shukla, K.K. (2010) Life Cycle Energy Analysis of Buildings: An Overview. Energy and Buildings, 42, 1592-1600.

[2] Pinky, D.L. and Sivakumar, P. (2014) A Case Study on Life Cycle Energy Use of Residential Building in Southern India. Energy and Buildings, 80, 247-259.

[3] Luisa, F., Cabeza, C.B., LaiaMiró, J.M. Morera, E.B. and Fernández, A.I. (2013) Low Carbon and Low Embodied Energy Materials in Buildings: A Review. Renewable and Sustainable Energy Reviews, 23, 536-542.

[4] Basbagill, J., Flager, F., Lepech, M. and Fischer, M. (2013) Application of Life-Cycle Assessment to Early Stage Building Design for Reduced Embodied Environmental Impacts. Building and Environment, 60, 81-92.

[5] Surekha, B., Hegde, M.N. and Jagadish, K.S. (2016) Energy and Building Materials. International Journal of Civil Engineering, 5, 13-24.

[6] Geoff, H. and Craig, J. (2008) Inventory of Carbon \& Energy (ICE). University of Bath, Colombia. 
[7] Satprem, M. and Varun, T. (2013) Embodied Energy of Various Materials and Technologies. Auroville Earth Institute, The City of Dawn.

[8] Praseeda, K.I., Venkatarama Reddy, B.V. and Monto, M. (2015) Embodied Energy Assessment of Building Materials in India Using Process and Input-Output Analysis. Energy and Buildings, 86, 677-686.

[9] Venkatarama Reddy, B.V. and Jagadish, K.S. (2003) Embodied Energy of Common and Alternative Building Materials and Technologies. Energy and Buildings, 35, 129-137.

[10] Schedule of Rates PW, P \& IWTD (2014-2015) Bengaluru, Government of Karnataka.

[11] Raghunath, S. and Abdelshani M. (2014) Building Classification Scheme for the City of Bangalore, Karnataka. Earthquake Risk Reduction on the Indian Subcontinent Project.

[12] IS1905 (1987) Code of Practice for Structural Use of Un-Reinforced Masonry, Bureau of Indian Standards, New Delhi.

[13] Deepak, B., Ramkishore, S. and Sawhney, R.L. (2014) Effect of Construction Materials on Embodied Energy and Cost of Buildings-A Case Study of Residential Houses in India up to $60 \mathrm{~m}^{2}$ of Plinth Area. Energy and Buildings, 69, 260-266.

[14] Marco, A.S., González, M.P., Kulakowski, L.G. and Breitenbach, F.K. (2014) Embodied Energy in Concrete and Structural Masonry on Typical Brazilian Buildings. International Journal of Civil, Environmental, Structural, Construction and Architectural Engineering, 8, 51-55.

\section{Notations Used}

\begin{tabular}{ccc}
\hline$\#$ & & Notations used \\
\hline 1 & EE & Embodied Energy \\
2 & PCC & Plain Cement Concrete \\
3 & RC & Reinforced Concrete \\
4 & SSM & Size Stone Masonry \\
5 & MRF & Moment Resisting Frame \\
6 & PLB & Partly Load Bearing \\
7 & HYSD Bar & High Yield Strength Deformed Bar \\
8 & M-Sand & Manufactured Sand \\
9 & SCB & Solid Concrete Block \\
10 & AAC Block & Autoclaved aerated concrete Blocks \\
11 & EHCB & Table-moulded Bricks \\
12 & TMB & Fly Ash Brick \\
13 & FA Brick & SMB \\
14 & HCB & Hollow clay block \\
15 & &
\end{tabular}




\section{Annexure A}

\section{Basic Calculation-Embodied Energy and Cost}

\begin{tabular}{|c|c|c|c|c|c|c|c|c|c|}
\hline Stru & tural Element: & & & BEAM & & & & & \\
\hline Quantit & of Concrete ( $\mathrm{m}$ & & & 9.96 & & & & & \\
\hline Gra & e of Concrete: & & & {$[1: 1.5: 3]$} & & & & & \\
\hline Material & Proportion & $\begin{array}{c}\text { Quantity } \\
\left(\mathrm{m}^{3}\right)\end{array}$ & Units & $\begin{array}{c}\text { EE value of } \\
\text { Material }\end{array}$ & Units & $\mathrm{EE}(\mathrm{MJ})$ & $\begin{array}{l}\text { Cost of } \\
\text { Material } \\
\text { (INR) }\end{array}$ & Units & $\begin{array}{l}\text { Cost } \\
\text { (INR) }\end{array}$ \\
\hline Cement & 1 & 1.81 & $\mathrm{~m}^{3}$ & 5184 & $\mathrm{MJ} / \mathrm{m}^{3}$ & 9383.04 & 16,800 & per $\mathrm{m}^{3}$ & 30,408 \\
\hline Sand & 1.5 & 2.72 & $\mathrm{~m}^{3}$ & 223.85 & $\mathrm{MJ} / \mathrm{m}^{3}$ & 608.87 & 1450 & per $\mathrm{m}^{3}$ & 3944 \\
\hline Gravel & 3 & 5.43 & $\mathrm{~m}^{3}$ & 186.29 & $\mathrm{MJ} / \mathrm{m}^{3}$ & 1011.55 & 900 & per $\mathrm{m}^{3}$ & 4887 \\
\hline $\begin{array}{c}\text { Reinforcement } \\
\text { steel }\end{array}$ & & 2230 & $\mathrm{~kg}$ & 26.84 & $\mathrm{MJ} / \mathrm{kg}$ & 59853.20 & 51 & per kg & 113,730 \\
\hline & & & & TOT & & 70,863 & & & 152,988 \\
\hline & ctural Element: & & & WALL & & & & & \\
\hline Quanti & of Masonry ( $\mathrm{m}$ & & & 68.59 & & & & & \\
\hline Quantity of & Mortar consume & $\left(\mathrm{m}^{3}\right)=$ & & 4.12 & & & & & \\
\hline Material & Proportion & Quantity & Units & $\begin{array}{c}\text { EE value of } \\
\text { Material }\end{array}$ & Units & $\mathrm{EE}(\mathrm{MJ})$ & $\begin{array}{c}\text { Cost of } \\
\text { Material } \\
\text { (INR) }\end{array}$ & Units & Cost (INR) \\
\hline Cement & 1 & 0.59 & $\mathrm{~m}^{3}$ & 5184 & $\mathrm{MJ} / \mathrm{m}^{3}$ & 3058.56 & 16,800 & per $\mathrm{m}^{3}$ & 9912 \\
\hline Sand & 6 & 3.53 & $\mathrm{~m}^{3}$ & 223.85 & $\mathrm{MJ} / \mathrm{m}^{3}$ & 790.19 & 1450 & per $\mathrm{m}^{3}$ & 5118.5 \\
\hline $\begin{array}{c}\text { Solid Concrete } \\
\text { Block }\end{array}$ & $150 \mathrm{~mm}$ & 2899 & no. & 7.8 & MJ/block & $22,612.20$ & 41 & per block & 118,859 \\
\hline $\begin{array}{l}\text { Solid Concrete } \\
\text { Block }\end{array}$ & $100 \mathrm{~mm}$ & 3549 & no. & 7.8 & MJ/block & $27,682.20$ & 31 & per block & 110,019 \\
\hline & & & & TO & & 55,340 & & & 248,582 \\
\hline
\end{tabular}

\section{Scientific Research Publishing}

Submit or recommend next manuscript to SCIRP and we will provide best service for you:

Accepting pre-submission inquiries through Email, Facebook, LinkedIn, Twitter, etc. A wide selection of journals (inclusive of 9 subjects, more than 200 journals)

Providing 24-hour high-quality service

User-friendly online submission system

Fair and swift peer-review system

Efficient typesetting and proofreading procedure

Display of the result of downloads and visits, as well as the number of cited articles

Maximum dissemination of your research work

Submit your manuscript at: http://papersubmission.scirp.org/

Or contact ojee@scirp.org 